\title{
Konsep Keguruan Dalam Pendidikan Berkaitan Dengan Keprofesionalan Dalam Profesi
}

\author{
Ahmad Parhani \\ Email: 2010111210010@mhs.ulm.ac.id \\ Program StudiPendidikanSejarahFakultasKeguruandanIlmuPendidikan \\ UniversitasLambungMangkurat \\ Banjarmasin
}

\begin{abstract}
Abstrak
Suatu profesi adalah sebuah pekerjaan yang memiliki tanggung jawab tunggi dan memerlukan sebuah keahlian, tidak semua pekerjaan dapat dikatakan sebagai profesi. Salah satu pekerjaan yang berkaitan dengan profesi adalah guru, yang mana berkaitan dengan pendidikan. Seorang guru haruslah benar- benar bertanggung jawab dan ahli dalam bidangnya. Pendidikan harus diutamakan dinegara ini karena akan membantu encerdaskan generasi bangsa untuk lebih beradab, cerdas, dan berketerampilan. Maka dari itu kaitannya dengan profesi keguruan adalah guru harus memiliki berbagai konsep dalam kompetensinya agar bisa profesional dalam bidang nya. Guru merupakan pekerjaan profesi, da pendidikan adalah suatu usaha sadar dan terencana untuk mewujudkan suasana belajar dan proses pembelajaran agar peserta didik secara aktif dapat mengembangkan potensinya untuk memiliki kekuatan spiritual keagamaan. Kemudian guru dalam konsep keprofesionalannya dalam pendidikan harus memiliki empat konsep kompetensi yang harus dimiliki agar bisa dikatakan profesional dan agar seorang guru bisa berkompeten dan berkualitas, yang pertama harus dimiliki adalah sebuah kompetensi pedagogik, memiliki kepribadian yang baik, Profesional dalam profesinya, dan memiliki jiwa sosial yang tinggi agar mampu berkomunikasi dengan baik. Baik itu dengan peserta didik, Orang tua peserta didik, dan masyarakat.
\end{abstract}

\section{PENDAHULUAN}

Profesi secara etimologi berasal dari kata profession (inggris) yang berasal dari bahasa latin profesus yang berarti mampu atau ahli suatu pekerjaan. Profesi dapat diartikan sebagai suatu pekerjaan atau jabatan yang menuntut keahlian, yang didapat melalui pendidikan dan latihan tertentu, menurut persyaratan khusus memiliki tanggung jawab dan kode etik tertentu ( Susanto, 2020:13 ).

Berdasarkan UU RI No.14 tahun 2005 tentang guru dan dosen pasal 1, Guru adalah pendidik profesional dengan tugas utama mendidik, mengajar, membimbing, mengarahkan, melatih, menilai, dan mengevaluasi peserta didik pada pendidikan anak usia dini jalur pendidikan formal, pendidikan dasar, dan pendidikan menengah ( Susanto, 2020:16 ). 


\section{PERAN GURU SEBAGAI SEBUAH PROFESI}

Guru merupakan suatu profesi, yang berarti suatu jabatan yang memerlukan keahlian khusus sebagai guru dan tidak dapat dilakukan oleh sembarang orang diluar bidang pendidikan. Walaupun pada kenyataannya masih terdapat guru yang tidak memiliki latar belakang pendidikan di bidang keguruan ( Susanto, 2020:17)

Berdasarkan UU RI No.14 tahun 2005 tentang guru dan dosen, guru bertugas mengajar, membimbing, mengarahkan, melatih, menilai, dan mengevaluasi peserta didik. Dosen bertugas mentransformasikan, mengembangkan, dan menyebar luaskan ilmu pengetahuan, teknologi, dan seni melalui pendidikan, penelitiaan, dan pengabdian kepada masyarakat. Menurut Noor Jamaluddin (1978 : 1) Guru adalah pendidik, yaitu orang dewasa yang bertanggung jawab memberi bimbingan atau bantuan kepada anak didik dalam perkembangan jasmani dan rohaninya agar mencapai kedewasaannya, mampu berdiri sendiri dapat melaksanakan tugasnya sebagai makhluk Allah khalifah di muka bumi, sebagai makhluk sosial dan individu yang sanggup berdiri sendiri.

Menurut Rickey (1987) sebagaimana dikutip Soetjipto dan Kosasi (20009:17) mengemukakan ciri ciri guru sebagai berikut : (1) Adanya komitmen dari para guru bahwa jabatan itu mengharuskan pengikutnya menjunjung tinggi martabat kemanusiaan lebih dari pada mencari keuntungan diri sendiri, (2) Suatu Profesi mensyaratkan orangnya mengikuti persiapan profesional dalam jangka waktu tertentu, (3) Harus selalu menambah pengetahuan agar terus menerus berkembang dalam jabatannya, (4) Memiliki kode etik jabatan, (5) Memiliki kemampuan intelektual menjawab masalah-masalah yang dihadapi, (6) Selalu ingin belajar terus menerus mengenai bidang keahlian yang ditekuni, (7) Menjadi anggota dari suatu organisasi profesi, (8) Jabatan itu dipandang sebagai suatu karir hidup (Susanto, 2020:16-17).

\section{GURU INDONESIA DAN TANTANGAN PROFESIONALISME}

Profesional sering diartikan sebagai suatu keterampilan teknis yang dimiliki seseorang. Profesional dalam banyak literatur diartikan jiga sebagai perilaku kerja yang mengutamakan kesempurnaan hasil dengan menjalankan mekanisme yang benar, berorientasi pada klien, dan menunjukan sikap tanggung jawab pada pekerjaan. Selanjutnya sikap profesional tersebut dalam praksisnya sering disebut profesionalisme. Profesionalisme mengacu pada ketentuan dalam menjalankan profesi yang telah memperoleh pengakuan dari suatu afiliasi, sikap mandiri dalam mengambil keputusan keprofesian, memahami dan mengikuti unsur regulatif terkait profesinya, memiliki dedikasi, dan menunjukan tanggung jawab sosial dalam menjalani profesi. Selain itu guru juga memiliki kompetensi profesionalnya yaitu yang artinya, kompetensi adalah kemampuan atau kecakapan, sedangkan Profesional menunjuk pada dua hal, yang pertama yaitu orang yang menyandang profesi, kedua penampilan seseorang dalam melakukan pekerjaan yang sesuai dengan profesinya. Jadi kompetensi profesional guru adalah kemampuan dan kewenangan guru dalam menjalankan profesi keguruannya, artinya guru piawai dalam 
melaksanakan profesinya dapat disebut sebagai guru yang kompeten dan profesional ( Susanto, 2020:56-63 ).

Dalam keprofesionalannya guru harus memiliki berbagai komponen, yang pertama yaitu kompetensi pedagogik, kompetensi ini adalah kemampuan yang harus dimiliki guru berkenaan dengan karakteristik siswa dari berbagai aspek yang ada pada diri siswa. Kemudian harus ada kompetensi kepribadian, yang berkaitan dengan tingkah laku pribadi guru itu sendiri yang kelak harus memiliki nilai luhur yang baik sehingga tercermin dalam perilaku sehari hari, Kemudian ada kompetensi profesional, yang berkaitan dengan kemampuan yang harus dimiliki guru dalam perencanaan dan pelaksanaan proses pembelajaran. Kompetensi sosial, adalah hal yang berkaitan dengan kemampuan guru dalam menyesuaikan diri pada tuntutan kerja dilingkungan sekitar pada waktu membawakan tugasnya sebagai guru ( Mulyasa, E. 2006 )

\section{SIMPULAN}

Guru merupakan suatu profesi yang artinya suatu jabatan yang memerlukan keahlian khusus, Guru adalah pendidik yang bertanggung jawab memberi bimbingan atau bantuan kepada peserta didiknya, dalam keprofesionalannya guru harus memiliki 4 Komponen yaitu Pedagogik, kepribadian yang baik, keprofesionalan, dan jiwa sosial.

\section{REFERENSI}

Efendi, I., Prawitasari, M., \& Susanto, H. (2021). Implementasi Penilaian Pembelajaran Pada Kurikulum 2013 Mata Pelajaran Sejarah. Prabayaksa: Journal of History Education, 1(1), 21-25.

Susanto, H. (2020). Profesi Keguruan. Banjarmasin: FKIP Universitas Lambung Mangkurat.

Susanto, H., \& Akmal, H. (2018). Efektivitas Penggunaan Aplikasi Pembelajaran Berbasis Mobile Smartphone Sebagai Media Pengenalan Sejarah Lokal Masa Revolusi Fisik Di Kalimantan Selatan Pada Siswa Sekolah Menengah Atas. HISTORIA: Jurnal Program Studi Pendidikan Sejarah, 6(2), 197-206.

Susanto, H., Irmawati, I., Akmal, H., \& Abbas, E. W. (2021). Media Film Dokumenter Masuknya Islam Ke Nusantara dan Pengaruhnya Terhadap Keterampilan Berpikir Kritis Siswa. HISTORIA: Jurnal Program Studi Pendidikan Sejarah, 9(1).

Syaharuddin, S., \& Susanto, H. (2019). Sejarah Pendidikan Indonesia (Era Pra Kolonialisme Nusantara sampai Reformasi). Banjarmasin: FKIP Universitas Lambung Mangkurat. 